\title{
Antecedents of Expectation and Continuance on Internet Group Buying Intention: An Empirical Study in Taiwan
}

\author{
Fan-Chuan Tseng ${ }^{1}$ \\ ${ }^{1}$ Department of Business and Management, University of Tainan, Tainan, Taiwan \\ Correspondence: Fan-Chuan Tseng, Department of Business and Management, University of Tainan, Tainan, \\ Taiwan. Tel: 886-6-2606173. E-mail: misfctseng@gmail.com
}

Received: July 16, 2018

Accepted: August 1, 2018

Online Published: September 6, 2018

doi:10.5539/ijbm.v13n10p130

URL: https://doi.org/10.5539/ijbm.v13n10p130

\begin{abstract}
Group buying websites have emerged as a major channel in e-commerce because they encourage consumers to negotiate deals with product/service providers. They also feature a "deal of the day" for consumers and an anticipated transaction volumes and discounts. Consumers can leverage their collective bargaining power to acquire products or services at discount prices when a minimum number of people are willing to purchase collectively. Considering the characteristics of collective bargaining power in Internet group buying and the continuance behavior of online consumers, this study integrated consumer psychological factors into expectation-confirmation theory to examine consumer cognitive processes. A survey was conducted to collect and analyze empirical data from ihergo - a popular Taiwanese group buying website. The results demonstrate that in the pre-purchase phase, consumer trust in group buying initiators and websites significantly affects their perceived risk and attitude toward Internet group buying deals, generating more positive expectations and group buying intentions. Moreover, in the post-purchase phase, a higher level of confirmation reflects higher trust and lower perceived risk. In addition, trust, perceived risk, and attitude significantly affect consumer satisfaction. This study suggests both practical and theoretical views for elucidating and enhancing the effectiveness of collective power in e-commerce.
\end{abstract}

Keywords: Internet group buying, expectation-confirmation theory, continuance intention, trust, perceived risk, attitude

\section{Introduction}

With the emergence of social media and increase in online social interaction, Internet shopping has developed from individual purchase activities to collective and social commerce, known as the customer-to-business (C2B) model. Internet group buying websites have become a significant channel in ecommerce because they encourage consumers to negotiate deals with product/service providers and feature a "deal of the day" for a set number of consumers and an anticipated transaction volumes and discounts (Gil-Or \& Rekettye, 2012). In group buying, consumers can leverage their collective bargaining power to acquire products or services at discount prices when a minimum number of people are willing to purchase collectively (Che, Peng, \& Hua, 2016; Hughes \& Beukes, 2012; Kauffman, Lai, \& Ho, 2010). Therefore, individual consumers can combine their purchasing power with that of other potential buyers, thereby, similar to big businesses, benefiting from economies of scale and lower prices (Dodge, 2000; Kauffman \& Wang, 2002). Moreover, consumers pursue and purchase daily deal items and can proactively act as agents to organize group buying and invite others to collectively purchase in large volumes to obtain discount prices or to ensure the availability of customized items. Previous practices in and research on e-commerce have typically focused on the importance of the transaction volume of Internet group buying deals, arguing that lower prices attract consumers and result in aggregate purchase. However, several Internet group buying service providers have closed or downsized their operations. For example, MobShop shut down in 2001 and Groupon has discontinued operations in seven countries since 2015. Because of the competitive nature of e-commerce and the strength of buyer bargaining power, the relationship between lower prices and high transaction volumes contravenes sellers' profitability (Kim \& Park, 2013). According to Gil-Or and Rekettye (2012), the feeling of power and control motivates consumers to adopt Internet group buying, share consumption experiences, and generate word-of-mouth. Therefore, the present study argues that the sustainability of Internet 
group buying depends on not only the purchase volume, but also the psychology and cognition of individual consumers.

According to Hughes and Beukes (2012), consumers develop their social relationships and share life experiences on the Internet, leading to them becoming co-creators of value. However, most Internet shoppers are strangers online. Product/service defects or deal deceptions can occur, lowering the purchase intentions on online consumers. Numerous concerns and challenges pertaining to security, privacy, and risk have emerged because consumers are typically unfamiliar with web vendors and they do generally not have opportunities to inspect the product or service directly (Belanger, Hiller, \& Smith, 2002; McKnight, Choudhury, \& Kacmar, 2002). Trust is a critical factor in the success of online transactions. When something or someone is considered reliable and appreciated, people more willingly engage in social exchanges and cooperative interactions are facilitated (Lu, Fan, \& Zhou, 2016; Nahapiet \& Ghoshal, 1998). Through the competence and goodwill of other online peers, consumers' perceived risk or purchase aversion can be reduced significantly (Hajli, Lin, Featherman, \& Wang, 2014; Kim, Ferrin, \& Rao, 2008; Kim \& Park, 2013). Accordingly, the success of Internet group buying is not merely related to the functionality of group buying websites; rather, it depends on the evaluation of trustworthiness and possible losses during such transactions.

Considering the characteristics of collective power in Internet group buying, this study examined consumer cognitive processes on the basis of expectation-confirmation theory (ECT). Bhattacherjee (2001) argued that consumer expectations, following a consumption experience, change their subsequent cognitive processes. Specifically, consumer post-purchase experiences provide more explicit information on the confirmation or disconfirmation of beliefs and subsequently increase or decrease their satisfaction and continuance intentions to make a purchase. In the diverse and dynamic e-commerce environment, Internet group buying consumers make purchase decisions collectively; their decisions are affected by product price or utility and derived from their individual psychological and emotional evaluations (Kauffman et al., 2010; Shiau \& Luo, 2012; Thaler, 1985). This study proposes a research framework by formulating hypothesized relationships to address the following questions: (1) Are psychological factors the antecedents of potential consumers' expectations for Internet group buying? (2) Can Internet group buying confirmation additionally affect consumers' cognition in the post-purchase phase? (3) Do consumers' psychological perceptions and purchase/continuance intentions differ between the pre-purchase and post-purchase phases?

\section{Literature Review}

\section{$2.1 E C T$}

ECT, originally proposed by Oliver (1980) in consumer behavior research investigating the purchase decision process, postulates that the confirmation or disconfirmation between anticipated outcomes and perceived performance influences consumers' post-purchase satisfaction and repurchase behavior. On the basis of ECT, the four main constructs, namely expectations, performance, confirmation, and satisfaction, have been adopted in the discipline of information systems (ISs) and combined with distinct technology acceptance aspects, such as perceived usefulness, self-efficacy, and subjective norms, to assess the effects on the continuance intentions of consumers toward IS products and services (Bhattacherjee, 2001; Chen, Liu, \& Lin, 2013; Lin, Wu, \& Tsai, 2005). Oliver and Winter (1987) argued that customer expectations are related to their current knowledge about a product or service. Expectations are the "comparison standard" (Halstead, 1999) by which perceived performance is evaluated. They not only enhance consumers' subsequent satisfaction with the Internet purchasing activity (McKinney, Yoon, \& Zahedi, 2002), but also their continuance intention to engage in social networking sites (Chang \& Zhu, 2012). Hamilton and Tee (2013) and Hamilton et al. (2013), proposed an expectations-values-outcomes (EVO) approach to explore online consumer feedback progresses from pre-activity expectations, through perceived value (such as service, performance, quality, economics, and satisfiers), to the assessment of outcomes including consumers' satisfaction, trust, and revisit intention. However, inevitable performance uncertainty in the context of e-commerce introduces risk and ambiguity and possibly influences consumer purchase intention and therefore must be further examined in the expectation-confirmation process.

\subsection{Trust}

According to Jarvenpaa et al. (2000) and Torche and Valenzuela (2011), trust provides a strategy for stimulating consumers' favorable attitudes and lowering their perceived risk in online contexts. In general, the concept of trust reflects the evaluation of one's competence, reliability, and genuine concern for others' welfare (McAllister, 1995; Ridings, Gefen, \& Arinze, 2002). A high degree of trust facilitates strengthening relationships and anticipation over future returns in terms of reliable actions to improve the effectiveness of buyers and sellers 
(Kuo, Tseng, \& Liou, 2007; Shapiro, 1987; Zucker, 1986). In the ecommerce environment, trust also determines customers' willingness to purchase goods or services online because, compared with face-to-face shopping, consumers can neither examine the physical features of a product nor experience a service in an online setting. In addition, because of online anonymity, consumers may be vulnerable to trading parties that intentionally cheat or provide defective products or services during transactions. Many studies (e.g., Feng, Lazar, \& Preece, 2004; Jarvenpaa, Knoll, \& Leidner, 1998; Kim \& Park, 2013; Leimeister, Ebner, \& Krcmar, 2005) have indicated that consumer' expectations for consumption reliability must be fulfilled before they are exposed to the uncertainties inherent in the digital context. Consumer perceptions of the competence, benevolence, and integrity of online vendors can influence consumer satisfaction (Dai, Luo, LIao, \& Cao, 2015; Xu, Cenfetelli, \& Aquino, 2016) and intention to engage in Internet transactions (Lu et al., 2016; McKnight et al., 2002). Yen and Chang (2015) confirmed that trust in Internet group buying website and auction initiators positively influences consumers' favorable attitudes toward group buying.

\subsection{Perceived Risk}

In the electronic marketplace, because of physical distance and the time lapse between purchase and delivery, customers may receive products with no proper shipment, no quick delivery service, or no guarantee of quality, resulting in low transaction performance (Kim, Xu, \& Gupta, 2012; Utz, Kerkhof, \& Bos, 2012). Concerns about uncertainty, security, and privacy when purchasing a product or service are major determinants of whether a consumer buys or rejects a product or service (Chen \& Dubinsky, 2003). The risk involved in online transactions is not limited to the product itself; the three major identified risk categories are performance, financial, and privacy risk. Specifically, performance risk refers to the likelihood of a product's functions or quality failing to meet expectations (Forsythe, Liu, Shannon, \& Gardner, 2006; Strader \& Shaw, 1999). Financial risk refers to concerns about the monetary loss when buying an expensive product, the risk of credit card information being stolen when making a purchase online, or having to pay additional expenses to return or repair a defective product (Aghekyan-Simonian, Forsythe, Kwon, \& Chattaraman, 2012). Privacy risk pertains to the insecure acquisition, storage, and dissemination of personal information leading to identity fraud or the misuse of private information online (Miyazaki \& Fernandez, 2001). To reduce consumer's perceived risk, several practical strategies have been proposed, through which consumers can seek reliable information to evaluate a brand's image/reputation or the price or quality of a certain product or service (Tan, 1999). Because of physical distance and time lapse between the purchase and delivery in the electronic marketplace, trust exerts a stronger influence on the acceptance of uncertainty and vulnerability (H.-W. Kim et al., 2012). With assurances about an online vendor's integrity, benevolence, and competence, online transactions with that vendor are considered trustworthy and thereby lead to low perceived risk and a positive attitude toward e-commerce (Gefen, Karahanna, \& Straub, 2003; Hsu, Chuang, \& Hsu, 2014; Utz et al., 2012). Dai et al. (2015) and Zain and Saidu (2016) have confirmed that consumer perceived risk is a significant antecedent of consumer satisfaction with online vendors.

\subsection{Attitude}

Attitude is a multidimensional construct that includes cognition, affect, and conation, expressing an individual's beliefs, feelings, and behavioral intentions (Rosenberg \& Hovland, 1960). For example, Koufaris, Priscilla, and Labarbera (2001) identified user-perceived control, playfulness, and perceived added value as crucial dimensions of consumer attitudes toward online shopping. Adopted from social psychology, the concept of attitude has been a critical concern in explaining and predicting specific human behaviors, reflecting a disposition to respond positively or negatively to an object (Ajzen, 2002; Ajzen \& Fishbein, 1980). In the literature on marketing and consumer behavior, people's attitudes toward products, services, or brands have received considerable attention because of their potential influence on consumer purchase decisions. According to Li and Zhang (2002), online shopping attitudes reflect the psychological state of consumers when they are attracted by product or service information through the Internet, how consumers evaluate the alternatives that fulfill their needs, and whether a transaction occurs. In addition, Argyriou and Melewar (2011) argued that understanding consumer attitudes and the process of attitude formation is critical because their attitudes influence their preferences and decisions to engage in online transactions. If purchasing online is a favorable, desirable, or excellent deal according to a product's features, quality, and money saving, the positive attitude derived from consumer gratification in online entertainment and informativeness enhances online purchase intentions (Lim \& Ting, 2012; Yen \& Chang, 2015).

\section{Research Model and Hypotheses}

In the diverse and dynamic e-commerce environment, Internet group buying consumers make purchase decisions collectively; the decisions are affected by a product's price or utility and are derived from their individual 
psychological and emotional evaluations (Kauffman et al., 2010; Shiau \& Luo, 2012; Thaler, 1985). However, most previous ECT-related studies have focused on the effect of confirmation on satisfaction and have neither elaborated on the possible antecedents of consumer expectations in the pre-purchase phase nor examined the subsequent psychological process in Internet group buying activity. In Section 2, we discuss ECT and three psychological factors in terms of trust, perceived risk, and attitude that are related to Internet group buying. The present study proposes an integrative research model based on ECT perspectives to examine the relationships among and effects of these factors on consumer expectations, intentions, and post-purchase confirmation and satisfaction in the context of Internet group buying. The corresponding hypotheses are described as follows.

\subsection{Antecedents of Expectation and Intention of Internet Group Buying}

According to Ajzen $(1988,2001)$, attitude refers to an individual's positive or negative evaluation of a given behavior, which can be determined by accessible behavioral beliefs and explain one's behavioral intention. Bhattacherjee (2008) argued that one's attitude toward a given behavior is derived from expectations about a trustee's behavior. According to Lu et al. (2016), trust beliefs from the perspectives of buyers and marketplaces are linked to the consumer purchase process. Yen and Chang (2015) asserted that trust is a significant factor associated with positive consumer attitudes toward group buying. Thus, the first hypothesis is proposed as follows:

H1: Consumer trust positively affects consumer attitude toward Internet group buying.

Moreover, an individual's concern about possible loss in electronic transactions affects how that person analyzes decisions made under risk (H.-W. Kim et al., 2012). This study proposes that two specific factors emerge in the process of Internet group buying - trust and perceived risk-and examines their interplay and influence on consumer attitudes. Thus, the following hypotheses are postulated:

H2: Consumer perceived risk negatively affects consumer attitude toward Internet group buying.

H3: Consumer trust negatively affects consumer perceived risk.

Attitude plays a critical role in consumer awareness of a brand and the assessment of its utility (Kim, Ko, Xu, \& Han, 2012). According to the EVO model proposed by Hamilton and Tee (2013), consumer-perceived value of a particular preactivity can not only contribute to consumers' expectations, but also determine the feedback loop on their behavioral intention. Thus, this study extends the pre-purchase expectation and revisit intention of online group buying with attitude by proposing the following two hypotheses:

H4: Consumer attitude toward Internet group buying positively affects consumer expectations.

H5: Consumer expectations positively affect consumer intentions toward Internet group buying.

\subsection{Cognitive Process in Confirmation and Satisfaction with Continuance Intention}

Bhattacherjee [2001] proposed a post-acceptance model to include a cognitive factor (i.e., perceived usefulness) to examine the changes in individuals' adoption experiences, indicating that their perceptions of usefulness form following their confirmation experience and further exert a positive influence on post-acceptance satisfaction. Similarly, Shiau and Luo [2012] confirmed that trust positively affects satisfaction in online group buying. In addition to the confident belief, perceived risk may be overwhelming in the context of ecommerce, affecting both pre-purchase attitudes and subsequent continuance decisions (Dai et al., 2015). Consistent with the argument of post-consumption cognitive change, this study considered the reconstitution of trust and perceived risk and examined the possible influences on the continuance evaluation process. Therefore, the following hypotheses are proposed:

H6: Consumer confirmation of Internet group buying positively affects consumer trust.

H7: Consumer confirmation of Internet group buying negatively affects consumer perceived risk.

H8: Consumer confirmation of Internet group buying positively affects consumer satisfaction.

H9: Consumer trust positively affects consumer satisfaction

H10: Consumer perceived risk negatively affects consumer satisfaction

Finally, empirical studies have demonstrated a positive relationship between individuals' post-purchase satisfaction and their intention to take action in the future. In the context of e-commerce, if satisfaction with e-commerce system attributes and service quality is high, consumers can more confidently participate in e-commerce activities and are more willing to purchase online (Liang et al., 2012; Shiau \& Luo, 2012). Therefore, this study argues that consumers with higher satisfaction derived from an Internet group buying 
experience will lead to future purchases through the social commerce community. Hence, the following hypothesis is proposed:

H11: Consumer satisfaction positively affects consumer continuance intention in Internet group buying.

Based on the hypothesized relationships among the constructs, the research model is presented in Figs. 1 and 2.

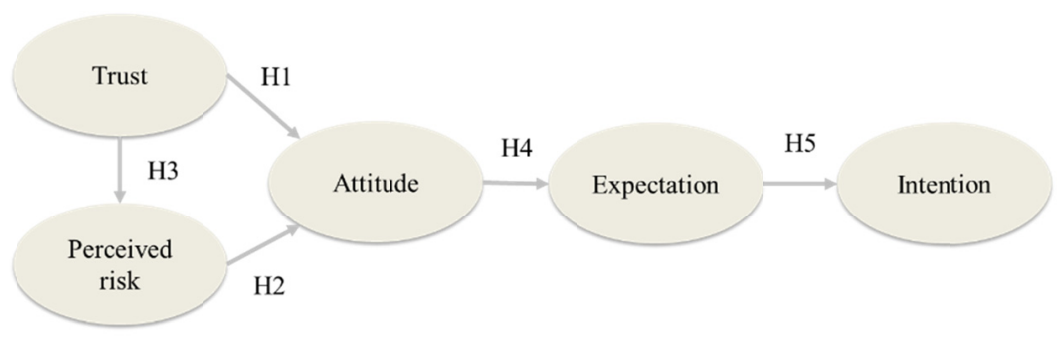

Fig.1. Phase One: Research on Pre-purchase

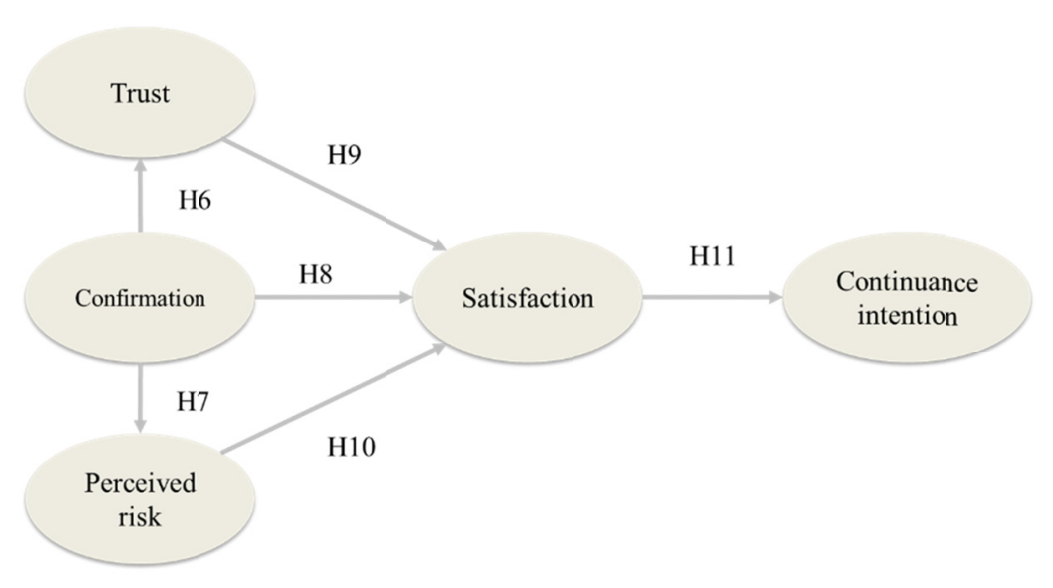

Fig. 2. Phase Two: Research on Post-purchase

\section{Research Design}

\subsection{Participants and Data Collection}

An online survey was conducted in Taiwan to collect and analyze empirical data from ihergo (www.ihergo.com), a popular Taiwanese online shopping website. Introduced in 2007, ihergo was the first community-based website in Taiwan to provide Internet group buying services. As of 2016, the number of registered members on the ihergo website exceeded one million, and the sales volume for March 2016 was up $81 \%$ from the same month in the previous year. This study explored the antecedents of consumer expectations and the subsequent cognitive processes in Internet group buying transactions. To track consumers' confirmation and continuance intention of Internet group buying, a two-phase survey was administered. The first phase was a pre-purchase survey, for which 285 responses were received; the second phase was a post-purchase evaluation survey (conducted 3 months after the first survey), from which 207 valid responses were received and subjected to further examination and analysis from both surveys.

\subsection{Measurement Development}

From the literature review, this study adopted eight constructs: trust, perceived risk, attitude, expectation, purchase intention, confirmation, satisfaction, and continuance intention. The operational definitions and measurement items of each construct are presented in Table 1. A questionnaire was developed to measure the constructs on a 5-point Likert scale, ranging from 1 (strongly disagree) to 5 (strongly agree). 
Table 1. Operational Definitions of Constructs and Measurement Items

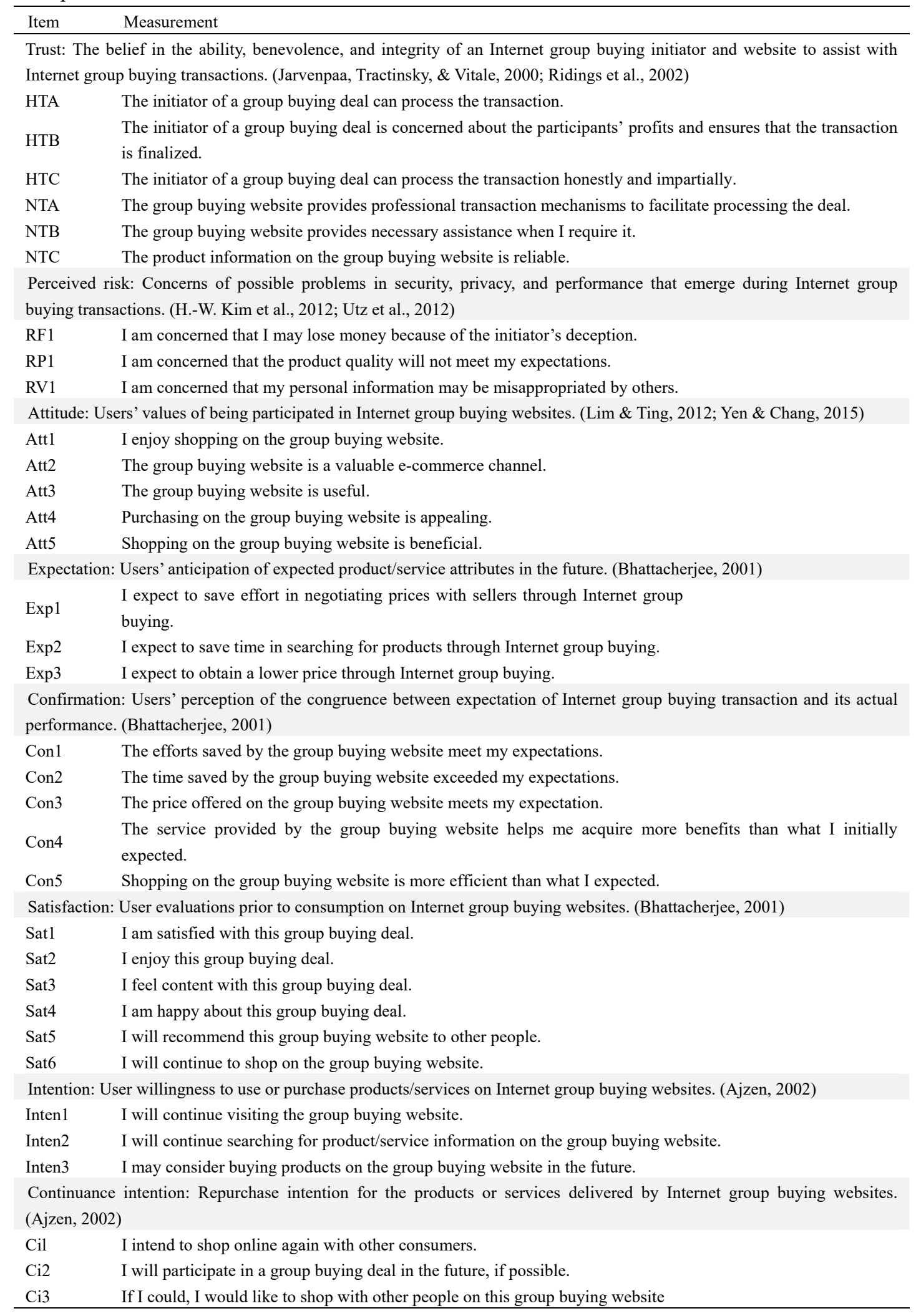

\section{Data Analysis}

\subsection{Descriptive Statistics and Common Method Bias}

As presented in Table 2, 79.7\% respondents were female. The most respondents were older than 25 years 
(57.5\%), and had an undergraduate degree (63.8\%). Approximately half of the respondents (50.7\%) had Internet group buying experience of 1-2 years, and a majority of the respondents (39.6\%) engaged in Internet shopping experience less than once a month.

Table 2. Descriptive Statistics of Respondents' Characteristics $(\mathrm{N}=207)$

\begin{tabular}{|c|c|c|c|}
\hline Characteristics & Items & Frequency & Percent \\
\hline \multirow{2}{*}{ Gender } & Male & 42 & 20.3 \\
\hline & Female & 165 & 79.7 \\
\hline \multirow{4}{*}{ Age } & $19-25$ years & 88 & 42.5 \\
\hline & $26-35$ years & 83 & 40.1 \\
\hline & $36-45$ years & 34 & 16.4 \\
\hline & $\geq 46$ years & 2 & 1.0 \\
\hline \multirow{3}{*}{ Education } & High school & 18 & 8.7 \\
\hline & Undergraduate & 132 & 63.8 \\
\hline & Postgraduate & 57 & 27.5 \\
\hline \multirow{4}{*}{$\begin{array}{l}\text { Internet group buying } \\
\text { experience }\end{array}$} & $<1$ year & 80 & 38.6 \\
\hline & $1-2$ years & 105 & 50.7 \\
\hline & $3-5$ years & 13 & 6.3 \\
\hline & $>5$ years & 9 & 4.3 \\
\hline \multirow{5}{*}{$\begin{array}{l}\text { Internet } \\
\text { frequency }\end{array}$} & Several times a week & 30 & 14.5 \\
\hline & Once a week & 12 & 5.8 \\
\hline & Several times a month & 66 & 32.0 \\
\hline & Once a month & 17 & 31.9 \\
\hline & Less than once a month & 82 & 39.6 \\
\hline
\end{tabular}

Before the hypotheses were tested, common method variance was investigated to test for common methods bias, which refers to the "the amount of spurious covariance shared among variables" (Malhotra, Kim, \& Patil, 2006) attributable to the measurement method, such as the scale type, response format, or content of specific items; or other biases such as halo effects and social desirability (Podsakoff, MacKenzie, \& Lee, 2003). This study conducted Harman's single-factor test by combining all of the items in the study in a single factor. The exploratory factor analysis from an unrotated factor solution was performed to examine whether the single factor explains the majority of variance. SPSS was used for the data analysis, the results of which indicated that the single factor accounted for $35.883 \%$ and $48.239 \%$ variance in the phase one and phase two models, respectively. Accordingly, the result does not explain much of the common method bias with a significant $50 \%$ variance of criteria.

\subsection{Measurement Model}

Partial least square (PLS) was used to assess the measurement model because of its "minimal demands on measurement scales, sample size, residual distributions" (Chin, Marcolin, \& Newsted, 1996). This study used SmartPLS to test the item reliability and construct validity. As shown in Table 3, the Cronbach's alpha values of each construct exceed 0.7 and the factor loadings of all items exceed 0.5, meeting the threshold (Cronbach, 1951; Nunnally, 1978). Convergent validity, referring to the degree to which different measures in a construct convey the same meaning (Hair, Black, Babin, \& Anderson, 2009), was assessed according to the average variance extracted (AVE) and composite reliability (CR). All AVE and CR values of each construct were higher than the recommended level -0.5 and 0.7, respectively. Consistent with Chin (1998), discriminant validity, measured by the square root of the AVE, was compared with the correlations among the constructs. As shown in Tables 4 and 5 , all square roots of the AVE values were higher than the correlations between all pairs of constructs. Thus, all the constructs and items fulfill the requirements of reliability, convergent validity, and discriminant validity. 
Table 3. CFA Results for Reliability and Validity of the Measurement Items

\begin{tabular}{|c|c|c|c|c|c|c|c|}
\hline Construct & Item & Mean & $\mathrm{SD}$ & $\begin{array}{c}\text { Factor } \\
\text { loading }\end{array}$ & AVE & $\mathrm{CR}$ & Cronbach's $\alpha$ \\
\hline \multirow{3}{*}{$\begin{array}{l}\text { Trust initiator } \\
\text { (First order, phase I) }\end{array}$} & HTA & 4.22 & 0.66 & 0.82 & \multirow{3}{*}{0.73} & \multirow{3}{*}{0.89} & \multirow{3}{*}{0.82} \\
\hline & НТВ & 3.56 & 0.57 & 0.85 & & & \\
\hline & HTC & 4.01 & 0.64 & 0.90 & & & \\
\hline \multirow{3}{*}{$\begin{array}{l}\text { Trust website } \\
\text { (First order, phase I) }\end{array}$} & NTA & 4.07 & 0.71 & 0.91 & \multirow{3}{*}{0.81} & \multirow{3}{*}{0.93} & \multirow{3}{*}{0.88} \\
\hline & NTB & 3.39 & 0.57 & 0.87 & & & \\
\hline & NTC & 3.96 & 0.69 & 0.82 & & & \\
\hline \multirow{2}{*}{$\begin{array}{l}\text { Trust I } \\
\text { (Second order, phase I) }\end{array}$} & HT1 & 3.96 & 0.53 & 0.88 & \multirow{2}{*}{0.79} & \multirow{2}{*}{0.88} & \multirow{2}{*}{0.73} \\
\hline & NT1 & 3.81 & 0.59 & 0.90 & & & \\
\hline \multirow{3}{*}{$\begin{array}{l}\text { Perceived risk I } \\
\text { (Phase I) }\end{array}$} & RF1 & 2.67 & 0.62 & 0.90 & \multirow{3}{*}{0.68} & \multirow{3}{*}{0.87} & \multirow{3}{*}{0.77} \\
\hline & RP1 & 3.16 & 0.73 & 0.80 & & & \\
\hline & RV1 & 3.52 & 1.04 & 0.78 & & & \\
\hline \multirow[t]{5}{*}{ Attitude } & Attl & 3.96 & 0.79 & 0.78 & \multirow{5}{*}{0.68} & \multirow{5}{*}{0.91} & \multirow{5}{*}{0.88} \\
\hline & Att2 & 3.97 & 0.80 & 0.84 & & & \\
\hline & Att3 & 4.05 & 0.75 & 0.87 & & & \\
\hline & Att4 & 4.23 & 0.68 & 0.83 & & & \\
\hline & Att5 & 4.31 & 0.64 & 0.80 & & & \\
\hline \multirow[t]{3}{*}{ Expectation } & Exp1 & 4.18 & 0.70 & 0.86 & & & \\
\hline & Exp2 & 4.07 & 0.80 & 0.84 & 0.71 & 0.88 & 0.80 \\
\hline & Exp3 & 4.17 & 0.76 & 0.88 & & & \\
\hline Intention & Inten 1 & 4.16 & 0.82 & 0.90 & & & \\
\hline & Inten2 & 4.18 & 0.80 & 0.93 & 0.85 & 0.94 & 0.91 \\
\hline & Inten3 & 4.29 & 0.75 & 0.94 & & & \\
\hline Trust initiator & HTD & 4.24 & 0.52 & 0.89 & & & \\
\hline (First order, phase II) & HTE & 3.66 & 0.55 & 0.90 & 0.81 & 0.93 & 0.88 \\
\hline & HTF & 4.10 & 0.61 & 0.92 & & & \\
\hline Trust website & NTD & 4.09 & 0.61 & 0.88 & & & \\
\hline (First order, phase II) & NTE & 3.41 & 0.51 & 0.87 & 0.80 & 0.92 & 0.87 \\
\hline & NTF & 4.00 & 0.59 & 0.93 & & & \\
\hline Trust 2 & HT2 & 4.00 & 0.50 & 0.91 & & & \\
\hline (Second order, phase II) & NT2 & 3.83 & 0.51 & 0.90 & 0.82 & 0.90 & 0.91 \\
\hline Perceived risk 2 & RF2 & 2.61 & 0.62 & 0.90 & & & \\
\hline (Second order, phase II) & $\mathrm{RP} 2$ & 2.98 & 0.83 & 0.86 & 0.63 & 0.83 & 0.72 \\
\hline & RV2 & 3.31 & 1.06 & 0.58 & & & \\
\hline Confirmation & Con1 & 4.11 & 0.68 & 0.77 & & & \\
\hline & Con2 & 4.03 & 0.75 & 0.75 & & & \\
\hline & Con 3 & 4.06 & 0.71 & 0.81 & 0.62 & 0.89 & 0.85 \\
\hline & Con4 & 4.00 & 0.73 & 0.81 & & & \\
\hline & Con5 & 4.00 & 0.84 & 0.80 & & & \\
\hline Satisfaction & Sat1 & 4.14 & 0.62 & 0.92 & & & \\
\hline & Sat2 & 4.15 & 0.64 & 0.91 & & & \\
\hline & Sat3 & 4.14 & 0.68 & 0.92 & & & \\
\hline & Sat4 & 4.18 & 0.66 & 0.93 & 0.79 & 0.96 & 0.95 \\
\hline & Sat5 & 4.19 & 0.70 & 0.82 & & & \\
\hline & Sat6 & 4.27 & 0.64 & 0.82 & & & \\
\hline Continuance Intention & Ci1 & 4.34 & 0.62 & 0.94 & & & \\
\hline & $\mathrm{Ci} 2$ & 4.39 & 0.60 & 0.94 & 0.88 & 0.96 & 0.93 \\
\hline & $\mathrm{Ci} 3$ & 4.38 & 0.60 & 0.95 & & & \\
\hline
\end{tabular}


Table 4. Discriminant Validity for the Research Constructs (Phase I)

\begin{tabular}{llcccc}
\hline Construct & A & B & C & D & E \\
\hline A. & Trust I & 0.89 & & & \\
B. $\quad$ Perceived Risk I & -0.21 & 0.83 & & \\
C. $\quad$ Attitude & 0.37 & -0.19 & 0.82 & 0.84 & 0.92 \\
\hline D. $\quad$ Expectation & 0.42 & 0.01 & 0.50 & 0.48 & 0.76 \\
\hline
\end{tabular}

Diagonal entries represent the square root of the AVE for each construct; off-diagonal entries represent the correlations among the constructs.

Table 5. Discriminant Validity for the Research Constructs (Phase II)

\begin{tabular}{|c|c|c|c|c|c|c|}
\hline \multicolumn{2}{|c|}{ Construct } & \multirow{2}{*}{$\frac{F}{0.79}$} & \multirow[t]{2}{*}{ G } & \multirow[t]{2}{*}{$\mathrm{H}$} & \multirow[t]{2}{*}{ I } & \multirow[t]{2}{*}{$\mathrm{J}$} \\
\hline F. & Confirmation & & & & & \\
\hline G. & Trust II & 0.59 & 0.90 & & & \\
\hline H. & Perceived Risk II & -0.32 & -0.41 & 0.80 & & \\
\hline I. & Satisfaction & 0.68 & 0.71 & -0.40 & 0.89 & \\
\hline J. & Continuance Intention & 0.47 & 0.55 & -0.25 & 0.72 & 0.94 \\
\hline
\end{tabular}

Diagonal entries represent the square root of the AVE for each construct; off-diagonal entries represent the correlations among the constructs.

\subsection{Hypothesis Testing}

After assessing the validity and reliability of the research constructs, we used PLS to test the hypotheses by measuring the model paths. The path coefficient of each hypothesis was found to be significant. The explained variance $\left(\mathrm{R}^{2}\right)$ of each dependent construct is presented in Figs. 3 and 4. The relationships among the constructs are described as follows.

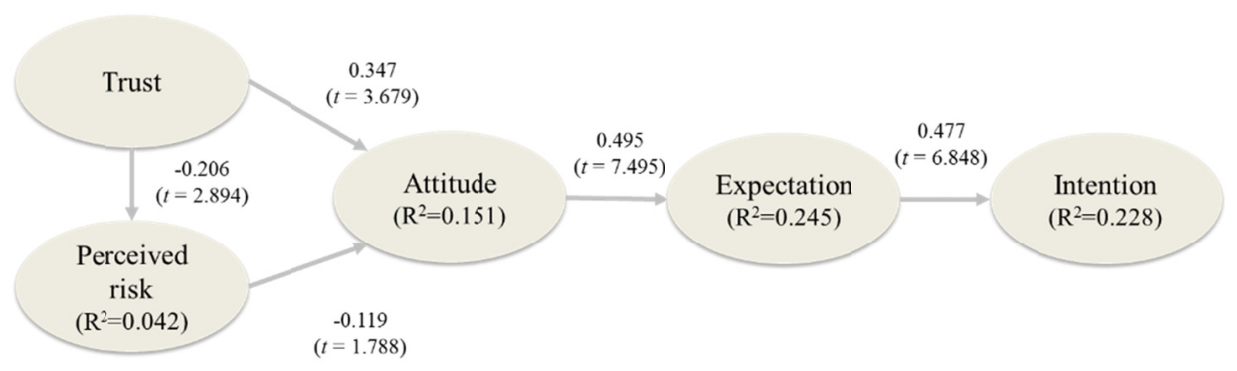

Fig. 3. Results of the PLS on Pre-purchase Phase 


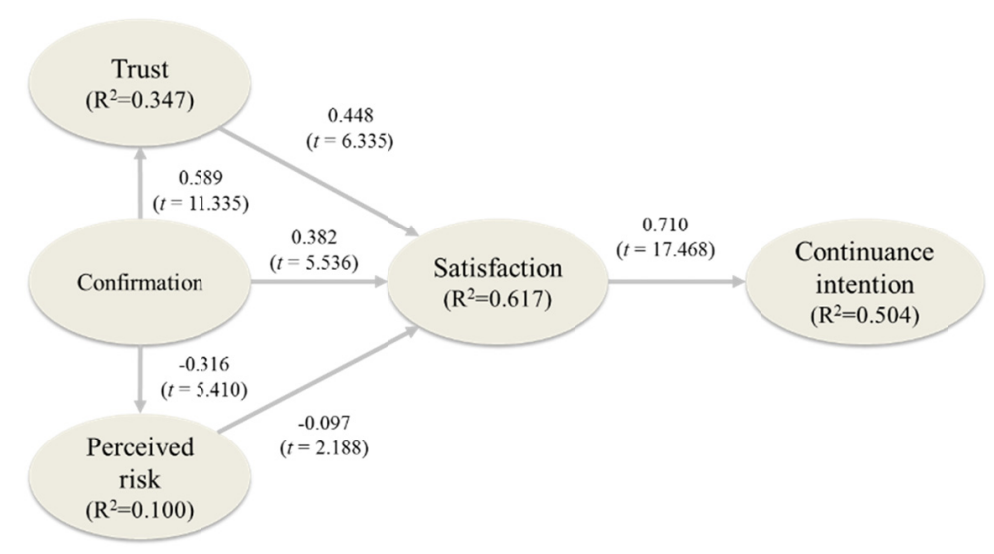

Fig. 4. Results of the PLS on Post-purchase Phase

The results reveal that attitude toward Internet group buying was significantly influenced by trust $(\mathrm{H} 1, \beta=0.347$, $\mathrm{p}<0.01)$ and perceived risk $(\mathrm{H} 2, \beta=-0.119, \mathrm{p}<0.05)$. The direct effect of trust on consumers' attitude was stronger than that of perceived risk. Trust also had a negative effect on perceived risk $(\mathrm{H} 3, \beta=-0.206, \mathrm{p}<0.01)$. Attitude was found to be a significant antecedent of expectation (H4, $\beta=0.495, \mathrm{p}<0.01)$. Regarding the expectation-confirmation process, the effect of expectation on Internet group buying intention is supported ( $\mathrm{H} 5$, $\beta=0.447, p<0.01)$. In the post-purchase phase, confirmation exhibited a significant influence on satisfaction (H8, $\beta=0.382, p<0.01)$. Consistent with ECT, satisfaction was found to be a critical antecedent of continuance intention in the context of Internet group buying (H11, $\beta=0.710, p<0.01)$. Finally, this study examined the extensive influence of confirmation on trust and perceived risk. The results confirmed that confirmation had a positive effect on trust $(\mathrm{H} 6, \beta=0.589, \mathrm{p}<0.01)$ and a negative effect on perceived risk $(\mathrm{H} 7, \beta=-0.316, \mathrm{p}<$ $0.01)$. Moreover, satisfaction was significantly affected by trust $(\mathrm{H} 9, \beta=0.448, \mathrm{p}<0.01)$ and perceived risk $(\mathrm{H} 10, \beta=-0.097, \mathrm{p}<0.01)$.

According to Hair et al. (2009), the predictive quality of a research model can be assessed according to the percentage of total variance it explains $\left(\mathrm{R}^{2}\right)$. The research results for the pre-purchase phase showed that trust in Internet group buying initiators and websites as well as perceived risk accounted for $15.1 \%$ of the variance in attitude toward group buying. Attitude toward Internet group buying accounted for $24.5 \%$ of the variance in expectation, which explained $22.8 \%$ of the variance in purchase intention through Internet group buying transactions. In the post-purchase phase, the research results reveal that confirmation, trust, and perceived risk collectively accounted for $61.7 \%$ of the variance in consumer satisfaction. Finally, continuance intention explained $50.4 \%$ of the variance in satisfaction. The $\mathrm{R}^{2}$ values indicated the importance of the relationships among consumers' perceptions, cognitions, and purchase intentions pertaining to Internet group buying activities.

To examine the difference between the pre- and post-purchase phases in Internet group buying, this study adopted an appropriate test statistics (Student $t$ statistics) for a two-group univariate analysis. The research constructs from both models were selected to validate whether the variable mean differed between before and after consumers' Internet group buying experiences. The research results showed that the means of perceived risk and intention differed significantly between the pre- and post-purchase phases. As shown in Table 6, perceived risk in the post-purchase phase (mean $=2.966$ ) was significantly lower than that in the pre-purchase phase $($ mean $=3.116)$. In addition, the consumers exhibited strong intentions (mean $=4.368)$ to re-engage in Internet group buying experience. Thus, this study suggests that Internet group buying affects consumers' perceived risk and continuance intentions, implying these two factors are critical in the context of Internet group buying. 
Table 6. Mean Differences in Perceived Risk and Purchase Intention (Pre-purchase vs. Post-purchase)

\begin{tabular}{rlcccc}
\hline Construct & \multicolumn{1}{c}{ Model } & Sample size & Mean (SD) & $t$ value & $p$ value \\
\hline \multirow{2}{*}{ Trust initiator } & Pre-purchase phase & 207 & $3.960(0.533)$ & \multirow{2}{*}{0.809} & 0.419 \\
& Post-purchase phase & 207 & $4.001(0.503)$ & & \\
\multirow{3}{*}{ Trust website } & Pre-purchase phase & 207 & $3.807(0.592)$ & \multirow{2}{*}{0.447} & 0.655 \\
& Post-purchase phase & 207 & $3.831(0.510)$ & & \\
\multirow{5}{*}{ Perceived risk } & Pre-purchase phase & 207 & $3.116(0.661)$ & \multirow{2}{*}{2.297} & \multirow{2}{*}{0.022} \\
& Post-purchase phase & 207 & $2.966(0.664)$ & & \\
\multirow{2}{*}{ Intention } & Pre-purchase phase & 207 & $4.211(0.727)$ & \multirow{2}{*}{2.457} & 0014 \\
& Post-purchase phase & 207 & $4.368 .571)$ & & \\
\hline
\end{tabular}

\section{Discussion and Implications}

\subsection{Key Findings}

With the rapid development of e-commerce in various aspects, such as $\mathrm{B} 2 \mathrm{~B}, \mathrm{~B} 2 \mathrm{C}, \mathrm{C} 2 \mathrm{C}, \mathrm{C} 2 \mathrm{~B}$, or mobile commerce models, the competitive substantiality has become an extremely critical concern for online companies. The dynamic pricing and transaction volume of Internet group buying attract consumers because these give them more control than they do sellers, and it motivates them to make deals collectively. However, the conflict between profitability and discount price guarantee has resulted in the closure or downsizing of several Internet group buying companies. A few studies have explored the psychological evaluation processes consumers employ when participating in Internet group buying, and have identified the significant effects of trust, conformity, reciprocity, and attitudes. These socio-psychological factors can be used in the group buying mechanism and to examine the dynamic cognition process by following consumers' expectation and confirmation.

In this study, a two-phase research framework was proposed by hypothesizing relationships between consumers' psychological factors (i.e., trust, perceived risk, and attitude) and ECT constructs (expectation, confirmation, satisfaction, and re-intention). A survey was conducted in Taiwan to collect and analyze empirical data (207 valid survey responses) from ihergo- a popular consumer-initiated group buying site in Taiwan. The research results demonstrate that in the pre-purchase phase, consumers' trust in group buying initiators and websites significantly affects both their perceived risk and attitude toward Internet group buying, resulting in more positive expectations and stronger group buying intentions. According to Kauffman and Wang (2001), the network externalities derived from the relationship between the size of a group of buyers and the anticipation of a price reduction plays a critical role in the context of Internet group buying. In ihergo, consumers are free to find and join any group buying transaction that they are interested in the item to buy. Moreover, they can initiate a deal in the website and aggregate buyers to reach the critical mass in an anticipated discount. Consumers benefit from other people's participation in terms of receiving a lower price and word-of-mouth recommendation and forming consumer coalitions in the online marketplace. This study argues that it is the basic reason that Internet buyers engage in group buying activities, rather than online auction or Internet retailing transactions.

In the post-purchase phase, a higher level of confirmation of Internet group buying experience reflects higher trust and lower perceived risk. Consistent with ECT perspectives, consumers' continuance intention toward Internet group buying is significantly influenced by their satisfaction. The results support that evaluations of both trustworthiness and risk contribute to positive attitudes and strengthen expectations toward Internet group buying. Consequently, more consumers are interested in a deal and subsequently ensure that the deal can be finalized. This study highlights the role of consumers' psychological factors in affecting their expectations pertaining to Internet group buying, specifically that such purchases save effort, time, and money. Discount business models are not the only mechanisms that can attract consumers. Because of the challenge of achieving a critical mass of buyers and the potential loss when adopting Internet group buying, the collective trust toward a deal initiator and group buying website, as determined by ability, reliability, and integrity, reduces buyers' concerns about financial loss, unsatisfactory quality of a product or service, or privacy concerns. Consistent with the argument of Bhattacherjee (2001), that consumer expectations and subsequent cognitive processes are subject to change, the Internet group buyers' confirmation of shopping experience further satisfies their demand through positive trust and minimized risk. Therefore, it is essential to maintain the social connection by providing feedback mechanism in the group buying website, where consumers deliver responses to share their purchasing experience as well as opinions for other consumer's reference and further collective transactions. 


\subsection{Implications}

This study provides both practical and theoretical implications for Internet group buying vendors to identify critical psychological factors affecting group buying decision processes and extends the ECT model with consumers' psychological perceptions in e-commerce research. From a practical viewpoint, both consumer trustworthiness and perceived risk play significant roles in the pre- and post-purchase phases of group buying. Before consumers place an order with other consumers on an Internet group buying website, they usually collect information to evaluate the reliability, effectiveness, and possible damages, and then make their decision on whether to make a purchase. The consequences of Internet group buying act as a form of feedback, which alters consumers' trust and perceived risk; only positive feedback increases satisfaction and future purchase intentions. Accordingly, Internet group buying businesses should be aware that ensuring that consumers' positive evaluations in the pre-purchase phase are essential to enhance their willingness to complete a collective online deal. To retain consumers for business growth, an evaluation of post-purchase cognitive processes should also be concerned with consumer expectations, confirmation, and psychological states (i.e., trust, perceived risk, and satisfaction) to ensure repeat purchases.

\subsection{Limitation and Suggestions}

The results of this study reveal several theoretical implications. First, this study adopted ECT perspectives to address the significant influences of expectation and confirmation in the context of Internet group buying. However, the literature focuses more on the effect of confirmation in the post-purchase phase. We believe that this is the first study to adopt the complete ECT model in the context of Internet group buying. Second, the results of this study reveal additional antecedents of consumer expectations and their influence on consumer attitudes toward Internet group buying. Third, the psychological constructs of trust and perceived risk were extended to the post-purchase phase, and these constructs were not only found to be significantly affected by consumer confirmation, but also exerted positive associations with consumer satisfaction. Furthermore, the results of a univariate analysis demonstrate a decrease in perceived risk at the post-purchase phase and an increase in intention to revisit the Internet group buying website.

Although this study provides practical and theoretical insights into Internet group buying, several limitations and suggestions for future research must be highlighted. First, this study collected data from one Internet group buying website in Taiwan. Generalizing the results may be difficult and must be treated circumspectly. Second, convenience sampling inevitably results in self-selection bias and over-representation of subjects with strong opinions. Therefore, future studies should adopt a more rigorous sampling technique and replicate this study in other Internet group buying websites to obtain more reliable and objective data. Finally, this study did not examine the variety of products or services purchased by consumers through Internet group buying. Specific categories of products or services may be more popular in the context of Internet group buying. Product information may provide valuable data for analysis in future research and ecommerce practices.

\section{References}

Aghekyan-Simonian, M., Forsythe, S., Kwon, W. S., \& Chattaraman, V. (2012). The role of product brand image and online store image on perceived risks and online purchase intentions for apparel. Journal of Retailing and Consumer Services, 19(3), 325-331. https://doi.org/10.1016/j.jretconser.2012.03.006

Ajzen, I. (1988). Attitudes, Personality, and Behavior. Chicago, IL: Dorsey Press.

Ajzen, I. (2001). Nature and Operation of Attitude. Annual Review of Sociology, 52, 27-58. https://doi.org/10.1146/annurev.psych.52.1.27

Ajzen, I. (2002). Perceived Behavioral Control, Self-Efficacy, Locus of Control, and the Theory of Planned $\begin{array}{llllll}\text { Behavior. Journal of Applied Social Psychology, } & 32, & \text { 1-20. }\end{array}$ https://doi.org/10.1111/j.1559-1816.2002.tb00236.x

Ajzen, I., \& Fishbein, M. (1980). Understanding Attitudes and Predicting Social Behavior. Englewood Cliffs, NJ: Prentice-Hall.

Argyriou, E., \& Melewar, T. C. (2011). Consumer attitudes revisited: a review of attitude theory in marketing research. International Journal of Management Reviews, 13(4), 431-451. https://doi.org/10.1111/j.1468-2370.2011.00299.x

Belanger, F., Hiller, J. S., \& Smith, W. J. (2002). Trustworthiness in electronic commerce: the role of privacy, security, and site attributes. Journal of Strategic Information Systems, 11(3/4), 245-270. https://doi.org/10.1016/S0963-8687(02)00018-5 
Bhattacherjee, A. (2001). Understanding information systems continuance: an expection-confirmation model. MIS Quarterly, 25(3), 351-370. https://doi.org/10.2307/3250921

Bhattacherjee, A. (2008). The formation of online trust. In I. Lee (Ed.), E-Business Models, Services, and Communications (2nd ed., pp. 325-343). Hershey, PA: Information Science Reference. https://doi.org/10.4018/978-1-59904-831-4.ch015

Chang, Y. P., \& Zhu, D. H. (2012). The role of perceived social capital and flow experience in building users' continuance intention to social networking sites in China. Computers in Human Behavior, 28(3), 995-1001. https://doi.org/10.1016/j.chb.2012.01.001

Che, T., Peng, Z., \& Hua, Z. (2016). Characteristics of online group-buying website and consumers intention to revisit: the moderating effects of visit channels. Electronic Commerce Research, 16(2), 171-188. https://doi.org/10.1007/s10660-016-9214-y

Chen, S. C., Liu, M. L., \& Lin, C. P. (2013). Integrating Technology Readiness into the Expectation-Confirmation Model: An Empirical Study of Mobile Services. CyberPsychology, Behavior \& Social Networking, 16(8), 604-612. https://doi.org/10.1089/cyber.2012.0606

Chen, Z., \& Dubinsky, A. J. (2003). A conceptual model of perceived customer value in E-commerce: a preliminary investigation. Psychology \& Marketing, 20(4), 323-347. https://doi.org/10.1002/mar.10076

Chin, W., Marcolin, B., \& Newsted, P. (1996, December 16-18, 1996). A partial least squares latent variable modeling approach for measuring interaction effects: Results from a monte carlo simulation study and voice mail emotion/adoption Study. Paper presented at the ICIS 1996, Cleveland, Ohio, USA.

Chin, W. W. (1998). The partial least square approach to structural equation modeling. In G. A. Marcoulides (Ed.), Modern Methods for Business Research (pp. 295-336). Mahway, NJ: Lawrence Erlbaum Assoicates.

Cronbach, L. (1951). Coefficient alpha and the internal structure of tests. Psychometrika, 31, 93-96. https://doi.org/10.1007/BF02310555

Dai, H., Luo, X., LIao, Q., \& Cao, M. (2015). Explaining consumer satisfaction of services: the role of innovagtiveness and emotion in an electronic mediated environment. Decision Support Systems, 70, 97-106. https://doi.org/10.1016/j.dss.2014.12.003

Dodge, J. (2000). Strength in numbers? A look at what group-buying sites have to offer consumers in search of computer gear. Retrieved from http://www.inc.com/magazine/20000915/20262.html

Feng, J., Lazar, J., \& Preece, J. (2004). Empathy and online interpersonal trust: a fragile relationship. Behaviour \& Information Technology, 23(2), 97-106. https://doi.org/10.1080/01449290310001659240

Forsythe, S., Liu, C., Shannon, D., \& Gardner, L. C. (2006). Development of a scale to measure the perceived benefits and risks of online shopping. Journal of Interactive Marketing, 20(2), 55-75. https://doi.org/10.1002/dir.20061

Gefen, D., Karahanna, E., \& Straub, D. (2003). Trust and TAM in online shopping: an integrative model. MIS Quarterly, 27(1), 51-90. https://doi.org/10.2307/30036519

Gil-Or, O., \& Rekettye, G. (2012). Social group buying pricing decisions. Far East Journal of Psychology and Business, 6(2), 22-29.

Hair, J. F., Black, W. C., Babin, B. J., \& Anderson, R. E. (2009). Multivariate Data Analysis (7th ed.). Upper Saddle River, NJ: Prentice Hall.

Hajli, N., Lin, X., Featherman, M., \& Wang, Y. (2014). Social word of mouth: how trust develops in the market. International journal of Market Research, 56(5), 673-689. https://doi.org/10.2501/IJMR-2014-045

Halstead, D. (1999). The use of comparison standards in customer satisfaction research and management: A review and proposed typology. Journal of Marketing Theory and Practice, 13-26. https://doi.org/10.1080/10696679.1999.11501837

Hamilton, J. R., Prideaux, M. C., \& Tee, S. (2013). Linking car racing attendee expectations and values with trust, satisfaction and loyalty outcomes. Paper presented at the The 12th International DSI and Asia Pacific DSI Conference, Bali, Indonesia.

Hamilton, J. R., \& Tee, S. (2013). SOCIAL NETWORK SITE VALUE DELIVERANCE FEEDBACK LOOPS. Paper presented at the The Thirteenth International Conference on Electronic Business, Singapore.

Hsu, M. H., Chuang, L. W., \& Hsu, C. S. (2014). Understanding online shopping intention: the roles of four 
types of trust and their antecedents. Internet Research, 24(3), 332-352. https://doi.org/10.1108/IntR-01-2013-0007

Hughes, S., \& Beukes, C. (2012). Growth and implications of social E-commerce and group buying daily deal sites: the case of Groupon and Livingsocial. International Business \& Economics Research Journal, 11(8), 921-934. https://doi.org/10.19030/iber.v11i8.7169

Jarvenpaa, S. L., Knoll, K., \& Leidner, D. E. (1998). Is anybody out there? antecedents of trust in global virtual teams. Journal of Management Information Systems, 14(4), 29-64. https://doi.org/10.1080/07421222.1998.11518185

Jarvenpaa, S. L., Tractinsky, N., \& Vitale, M. (2000). Consumer Trust in an Internet Store. Information Technology and Management, 1(12), 45-71. https://doi.org/10.1023/A:1019104520776

Kauffman, R. J., Lai, H., \& Ho, C. T. (2010). Incentive mechanisms, fairness and participation in online group-buying auctions. Electronic Commerce Research and Applications, 9(3), 249-262. https://doi.org/10.1016/j.elerap.2008.11.009

Kauffman, R. J., \& Wang, B. (2002). Bid together, buy together: on the efficacy of group-buying business models in Internet-based selling. In P. B. Lowry, J. O. Cherrington, \& R. R. Watson (Eds.), Handbook of Electronic Commerce in Business and Society (pp. 99-137). Boca Raton, FL: CRC Press.

Kim, D. J., Ferrin, D. L., \& Rao, H. R. (2008). A trust-based consumer decision-making model in electronic commerce: the role of trust, perceived risk, and their antecedents. Decision Support Systems, 44(2), 544-564. https://doi.org/10.1016/j.dss.2007.07.001

Kim, H. W., Xu, Y., \& Gupta, S. (2012). Which is more important in Internet shoping, perceived price or trust? Electronic Commerce Research and Applications, 11(3), 241-252. https://doi.org/10.1016/j.elerap.2011.06.003

Kim, K. H., Ko, E., Xu, B., \& Han, Y. (2012). Increasing customer equity of luxury fashion brands through nurturing consumer attitude. Journal of Business Research, 65(10), 1495-1499. https://doi.org/10.1016/j.jbusres.2011.10.016

Kim, S., \& Park, H. (2013). Effects of various characteristics of social commerce (s-commerce) on consumers' trust and trust performance. International Journal of Information Management, 33(2), 318-332. https://doi.org/10.1016/j.ijinfomgt.2012.11.006

Koufaris, M., Priscilla, A. K., \& Labarbera, A. (2001). Consumer behavior in web-based commerce: an empirical study. International Journal of Electronic Commerce, 6(2), 115-138. https://doi.org/10.1080/10864415.2001.11044233

Kuo, F. Y., Tseng, F. C., \& Liou, D. Y. (2007). Understanding the effects of relationships on the intention of a firm to adopt e-banking. International Journal of Electronic Finance, 1(4), 484-501. https://doi.org/10.1504/IJEF.2007.012901

Leimeister, J. M., Ebner, W., \& Krcmar, H. (2005). Design, implementation, and evaluation of trust-supporting components in virtual communities for patients. Journal of Management Information Systems, 21(4), 101-135. https://doi.org/10.1080/07421222.2005.11045825

Li, N., \& Zhang, P. (2002). Consumer online shopping attitudes and behavior: An assessment of research. Paper presented at the 2002 Eighth Americas Conference on Information Systems, Dallas, Texas.

Lim, W. M., \& Ting, D. H. (2012). E-shopping: an analysis of the uses and gratification theory. Modern Applied Science, 6(5), 48-63. https://doi.org/10.5539/mas.v6n5p48

Lin, C. S., Wu, S., \& Tsai, R. J. (2005). Integrating perceived playfulness into expectation-confirmation model for web portal context. Information \& Management, 42(5), 683-693. https://doi.org/10.1016/j.im.2004.04.003

Lu, B., Fan, W., \& Zhou, M. (2016). Social presence, trust, and social commerce purchase intention: An empirical research. Computers in Human Behavior, 56, 225-237. https://doi.org/10.1016/j.chb.2015.11.057

Malhotra, N. K., Kim, S. S., \& Patil, A. (2006). Common method variance in IS research: a comparison of alternative approaches and a reanalysis of past research. Management Science, 56(12), 1865-1883. https://doi.org/10.1287/mnsc.1060.0597

McAllister, D. J. (1995). Affect- and cognition-based trust as foundations for interpersonal cooperation in 
organizations. Academy of Management Journal, 38(1), 24-59.

McKinney, V., Yoon, K., \& Zahedi, F. M. (2002). The Measurement of Web-Customer Satisfaction: An Expectation and Disconfirmation Approach. Info. Sys. Research, 13(3), 296-315. https://doi.org/10.1287/isre.13.3.296.76

McKnight, D. H., Choudhury, V., \& Kacmar, C. (2002). The impact of initial consumer trust on intentions to transact with a web site: a trust building model. Journal of Strategic Information System, 11(3/4), 297-323. https://doi.org/10.1016/S0963-8687(02)00020-3

Miyazaki, A. D., \& Fernandez, A. (2001). Consumer perceptions of privacy and security risks for online shopping. Journal of Consumer Affairs, 35(1), 27-44. https://doi.org/10.1111/j.1745-6606.2001.tb00101.x

Nahapiet, J., \& Ghoshal, S. (1998). Social capital, intellectual capital, and the organizational advantage. Academy of Management Review, 23(2), 242-266. https://doi.org/10.5465/amr.1998.533225

Nunnally, J. C. (1978). Psychometric theory. New York: McGraw-Hill.

Oliver, R. L. (1980). A cognitive model of the antecedents and consequences of satisfaction decisions. Journal of Advertising Research, 17(4), 460-469. https://doi.org/10.2307/3150499

Oliver, R. L., \& Winer, R. S. (1987). A framework for the formation and structure of consumer expectations: Review and propositions. Journal of Economic Psychology, 8(4), 469-499. https://doi.org/10.1016/0167-4870(87)90037-7

Podsakoff, P. M., MacKenzie, S. B., \& Lee, J.-Y. (2003). Common method biases in behavioral research: a critical review of the literature and recommended remedies. Journal of Applied Psychology, 88(5), 879-903. https://doi.org/10.1037/0021-9010.88.5.879

Ridings, C. M., Gefen, D., \& Arinze, B. (2002). Some antecedents and effects of trust in virtual communities. Journal of Strategic Information Systems, 11, 271-295. https://doi.org/10.1016/S0963-8687(02)00021-5

Rosenberg, M. J., \& Hovland, C. I. (1960). Cognitive, Affective and Behavioral Components of Attitudes. In M. J. Rosenberg \& C. I. Hovland (Eds.), Attitude organization and change: An analysis of consistency among attitude components. New Haven: Yale University Press.

Shapiro, S. P. (1987). The social control of impersonal trust. American journal of Sociology, 93, 623-658. https://doi.org/10.1086/228791

Shiau, W. L., \& Luo, M. M. (2012). Factors affecting online group buying intention and satisfaction: a social exchange theory perspective. Computers in Human Behavior, 28(6), 2431-2444. https://doi.org/10.1016/j.chb.2012.07.030

Strader, T. J., \& Shaw, M. J. (1999). Consumer cost differences for traditional and internet markets. Internet Research, 9(2), 82-92. https://doi.org/10.1108/10662249910264819

Tan, S. J. (1999). Strategies for reducing consumers' risk aversion in Internet shopping. Journal of Consumer Research, 16(2), 163-180.

Teo, T. S. (2002). Attitudes toward online shopping and the Internet. Behaviour \& Information Technology, 21(4), 259-271. https://doi.org/10.1080/0144929021000018342

Thaler, R. (1985). Mental accounting and consumer choice. Marketing Science, 4(3), 199-214. https://doi.org/10.1287/mksc.4.3.199

Torche, F., \& Valenzuela, E. (2011). Trust and reciprocity: A theoretical distinction of the sources of social capital. European Journal of Social Theory, 14(2), 181-198. https://doi.org/10.1177/1368431011403461

Utz, S., Kerkhof, P., \& Bos, J. v. d. (2012). Consumers rule: how consumer reviews influence perceived trustworthiness of online stores. Electronic Commerce Research and Applications, 11(1), 49-58. https://doi.org/10.1016/j.elerap.2011.07.010

$\mathrm{Xu}$, J., Cenfetelli, R. T., \& Aquino, K. (2016). Do different kinds of trust matter? An examination of the three trusting beliefs on satisfaction and purchase behavior in the buyer-seller context. Journal of Strategic Information Systems, 25, 15-31. https://doi.org/10.1016/j.jsis.2015.10.004

Yen, C., \& Chang, C.-M. (2015). Unity is strength: Understanding users' group buying behavior in Taiwan from a collectivism perspective. Journal of Electronic Commerce Research, 16(2), 109-122.

Zain, O. M., \& Saidu, M. B. (2016). The Customers Satisfaction on Retailers' Brand Products: A Study on 
Selected Areas in Klang Valley. Procedia Economics and Finance, 35, 418-427. https://doi.org/10.1016/S2212-5671(16)00052-6

Zucker, L. G. (1986). Production of Trust: Institutional Sources of Economic Structure: 1840-1920. In B. Staw \& L. Cummings (Eds.), Research in Organizational Behavior (Vol. 8, pp. 53-111).

\section{Copyrights}

Copyright for this article is retained by the author(s), with first publication rights granted to the journal.

This is an open-access article distributed under the terms and conditions of the Creative Commons Attribution license (http://creativecommons.org/licenses/by/4.0/). 